\title{
Participation in university activities for the elderly: Motivations of Brazilian and Spanish Seniors
}

\author{
A participação em atividades universitárias para idosos: motivações de brasileiros e espanhóis
}

La participación de ancianos en actividades universitarias para la tercera edad: las motivaciones de brasileños y españoles

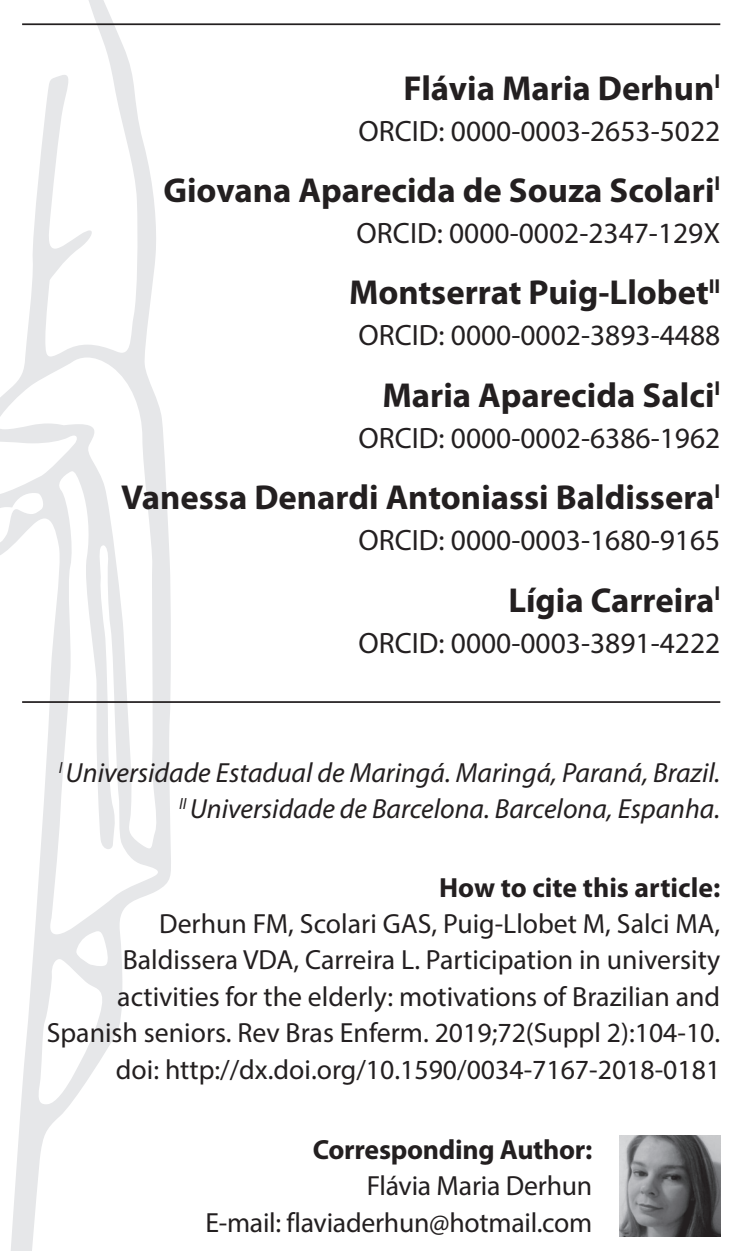

Submission: 04-01-2018 Approval: 11-11-2018

\begin{abstract}
Objective: To understand the reasons that lead Brazilian and Spanish seniors to enroll in a university for the elderly. Method: A qualitative study that used Symbolic Interactionism as a theoretical reference and the Grounded Theory as a methodological reference. We interviewed 44 seniors enrolled in universities for the elderly from two countries (Brazil and Spain) between October 2014 and May 2016. Results: The motivations were related to the necessity of occupying the free time, even for improving health; to the opportunity of access to university learning bypassing formal education criteria; to the expansion of social relations, sought through the creation of new friendships, the desire to know other people's life experiences, and the exchange of knowledge. Final considerations: Older people have sought in universities for the elderly a pleasurable way of learning and occupying the free time.

Descriptors: Aging; Aged; Learning; Universities; Retirement.
\end{abstract}

\section{RESUMO}

Objetivo: Compreender os motivos que levam idosos brasileiros e espanhóis a matricularem-se na universidade aberta à terceira idade. Método: Estudo qualitativo que utilizou o Interacionismo Simbólico como referencial teórico e a Teoria Fundamentada nos Dados como referencial metodológico. Foram entrevistados 44 idosos matriculados em universidades abertas à terceira idade de dois países (Brasil e Espanha) no período de outubro de 2014 a maio de 2016. Resultados: As motivações vincularam-se à necessidade de ocupação do tempo disponível, inclusive para melhoria da saúde; à oportunidade de acesso ao aprendizado na universidade sem os critérios do ensino formal e; à ampliação das relações sociais, buscada por meio da criação de novas amizades, pelo anseio em conhecer as experiências vivenciadas por outras pessoas e pela troca de saberes. Considerações finais: Os idosos buscaram nas universidades abertas à terceira idade uma forma prazerosa de aprender e ocupar o tempo disponível.

Descritores: Envelhecimento; Idoso; Aprendizagem; Universidades; Aposentadoria.

\section{RESUMEN}

Objetivo: Conocer cuáles fueron las razones de ancianos brasileños y españoles para inscribirse en la universidad abierta a la tercera edad. Método: Estudio cualitativo que utilizó como referencial teórico el Interaccionismo Simbólico y como referencial metodológico la Teoría Fundamentada en los Datos. Se entrevistaron 44 ancianos matriculados en universidades abiertas a la tercera edad de dos países (Brasil y España), en el período de octubre de 2014 a mayo de 2016. Resultados: Las motivaciones fueron las siguientes: la necesidad de ocupar el tiempo libre, incluso para mejorar la salud; la oportunidad de acceder al aprendizaje en la universidad sin los criterios de la enseñanza formal; y la ampliación de las relaciones sociales, por medio de nuevas amistades, por el anhelo de conocer las experiencias vivenciadas por otras personas y por el intercambio de saberes. Consideraciones finales: Los ancianos buscaron una forma placentera de aprender y de ocupar el tiempo libre en las universidades abiertas a la tercera edad. Descriptores: Envejecimiento; Anciano; Aprendizaje; Universidades; Jubilación. 


\section{INTRODUCTION}

Aging has stood out as a learning phase and no longer as a period of functional decline and loss. As a result, universities in many countries offer educational programs for the elderly ${ }^{(1)}$, commonly called universities for the old age (UNATI, in the Portuguese acronym). Such initiatives are configured as programs offering non-formal permanent education so that aged people can acquire, validate and share knowledge with their peers and other generations ${ }^{(2-3)}$.

Unlike the formal education offered by traditional universities, which has the role of training people for a variety of professions and careers $^{(4)}$, UNATI's activities are not intended to professionalize older students but to offer diverse learning opportunities and relationships ${ }^{(2-3)}$. In UNATI, intellectual, physical and social activities are offered so that the elderly can adapt to a context of constant reformulation, which encompasses social, cultural, economic and scientific changes ${ }^{(3)}$. The purpose of this is to provide active aging ${ }^{(5)}$ with quality of life $\mathrm{e}^{(6)}$.

In considering the social importance of UNATI, it is deemed necessary to understand the motivations that lead these people to search for such higher education. Although there are research studies exploring the theme $e^{(1,7-9)}$, no study has been performed to date for understanding the desires of older people from different countries to enroll in UNATI. Knowledge about this subject is considered still incipient to inform professionals, policymakers and researchers in the area about how such a process occurs.

In the perspective of Symbolic Interactionism, the individual confronted with a given situation develops meanings and interprets and shapes them from his point of view in order to direct his actions ${ }^{(10)}$. From this assumption, and considering that older people of different countries and cultures experience different opportunities; that their motivations are full of meanings and configure themselves as fundamental to understand their behaviors, we ask: what are the motivations that lead Brazilian and Spanish elders to seek UNATI? Are motivations influenced by the socioeconomic and cultural context in which the elderly live?

\section{OBJECTIVE}

To understand the reasons that lead Brazilian and Spanish seniors to enroll in UNATI.

\section{METHOD}

\section{Ethical aspects}

All ethical precepts currently effective for research involving human beings were followed. In Spain, the project was approved by the Bioethics Commission of the University of Barcelona (UB), and in Brazil it was approved by the Research Ethics Committee of the State University of Maringá (UEM). All of the participants were briefed about the research and signed the Free and Informed Consent Form. Participants were identified with the letter I, meaning Interviewee, followed by Arabic numerals and the institution where they were enrolled.

\section{Hypothesis}

Because Brazilian and Spanish seniors are situated in distinct socioeconomic and cultural contexts, they have different motivations to seek UNATI.

\section{Study design and theoretical-methodological reference}

This is a qualitative research that used Symbolic Interactionism as its theoretical reference ${ }^{(10)}$ and Grounded Theory (GT) as its methodological reference ${ }^{(11)}$. The precepts of the Consolidated criteria for reporting qualitative research ${ }^{(12)}$ were respected.

\section{Study scenario}

This study was performed with elderly people in two countries, Spain and Brazil. In Spain, where the total population is $46,122,000$ people, life expectancy at birth is 80.2 years and the elderly share of the population is 30\%. In Brazil, with 207,848,000 inhabitants, life expectancy is 75.4 years and $13.2 \%$ of the population are elderly ${ }^{(13)}$.

The study scenario in Spain was the University of Barcelona's UNATI (UNATI/UB), located in the city of Barcelona, which belongs to the autonomous community of Catalonia. UNATI/UB offers 970 vacancies filled by people 55 years of age or older, who need to pay an enrollment fee in order to join. The program has 11 disciplines, namely: food and gastronomy, astronomy and meteorology, arts, library and archives in the digital age, human biology and biodiversity, health sciences, philosophy, art history, history and territory, languages and literature, and psychology.

The second scenario was the State University of Maringá $₫ s$ UNATI (UNATI/UEM), located in Maringá, PR, Brazil, which offers vacancies for 400 students aged 60 or over. There is no registration fee and all vacancies are filled. It offers 40 disciplines included in six different areas of knowledge: art and culture, communicative processes and procedures, physical and mental health, physical and social environment, law and citizenship, and the humanities.

Both UNATI began activities in 2010 and do not require any previous training by the student. Available vacancies are distributed by lot because the demand outnumbers the supply.

\section{Data source}

The inclusion criteria were: to be aged and to be enrolled in at least one course at UNATI/UB or UNATI/UEM during the study period. Individuals were approached via telephone on the interest in participating in the survey and through verbal acceptance the interviews were scheduled to happen in the place of their choice. Four interviews took place in the interviewees' home and the others in the premises of UNATI. There was no refusal to participate in the study.

The researchers received from each UNATI a list containing data on the elderly enrolled, such as name, gender, age, time attending UNATI, disciplines in progress and completed in previous years, telephone contact, among others. The first people interviewed were indicated by the UNATI/UB coordination, one 
female and one male. According to the inferences that emerged in the concomitant data collection and analysis process, it was deemed necessary to include aged individuals with different characteristics, thus initiating the use of theoretical sampling.

To that end, we contacted elderly people enrolled in different disciplines and with different sociodemographic characteristics, such as age (between 60 and 69 years, 70 and 79 years and 80 and over), civil status (married, divorced, widowed, and single), education (elementary education, high school and higher education) and occupation (retired, exercising work activity or retiring and exercising work activity). Thus, the first Sampling Group (SG) was composed of 22 Spanish elderly enrolled in the UNATI/UB.

We also deemed important to vary the subjects regarding their sociocultural context, so as to broaden the points of view for understanding the phenomenon. In this way, the second SG was composed of 22 elderly people linked to a Brazilian UNATI, UNATI/ UEM. This group was also started with a female and a male, both indicated by the UNATI/UEM, and as the inferences emerged we sought to vary the characteristics, as we did about the first SG.

\section{Collection and organization of data}

Data collection took place between October 2014 and June 2016 through individual interviews conducted by researchers who had no relationship with the participants. The interviews were based on the following guiding question: Why did you decide to enroll in UNATI? The interviews had an average duration of 30 minutes and the audios were digitally recorded and transcribed in full.

Data collection and analysis occurred concomitantly, as recommended by the method ${ }^{(11)}$. Memos were used throughout the research process to inform the sampling direction, data collection and analysis. There was no need to modify the instrument along the study and each person was interviewed only once.

The data were coded until reaching theoretical saturation. This allowed data collection to be interrupted when no information added or modified the existing ones and also determined the number of participants. Data from UNATI/UB interviewees in Spanish were transcribed and translated into Portuguese by one of the researchers, who is fluent in both languages. There was no translation validation.

\section{Data analysis}

For data analysis we used the steps of open, axial and selective coding. In open coding, the transcribed interview was carefully read. The data were analyzed line by line and the incidents were named with preliminary codes and later grouped and reorganized by similarities and differences for the development of conceptual codes ${ }^{(11)}$.

During axial coding, conceptual codes were regrouped to systematically generate and develop categories and their subcategories, as well as to relate them. In the last step, selective coding, categories were refined. From this process we obtained the central category or phenomenon "The pursuit of permanent non-formal education as a pleasant way to use the available time" and its categories "UNATI as a strategy for using free time", "the opportunity for access to learning in the university" and "the search of expansion and/or improvement of social relations".

\section{RESULTS}

A total of 44 people participated, of whom 22 were female. The age ranged from 60 to 83 years, with a mean of 71 years. In relation to marital status, 29 were married, three divorced, 10 widowed and two single. Three had basic education, 16 secondary education, 19 higher education, and six incomplete higher education. As for work status, 37 were retired and did not engage in any paid activity, four had paid employment and were not retired, and three, despite retirees, had a paid employment relationship. Of the total, 36 reported the presence of at least one chronic condition and the most cited ones were related to cardiovascular, osteoarticular, endocrine and ophthalmologic systems.

Data analysis allowed to develop an understanding of the reasons that led Brazilian and Spanish seniors to seek UNATI programs. Such motivations resulted from the symbolic interpretation made about the situations experienced and encouraged the pursuit of UNATI.

\section{Universities for the old age (UNATI) as a strategy to use free time}

For Brazilian and Spanish seniors, the retirement process was expressed by a set of meanings linked to idleness, which resulted from the wide availability of time and the scarcity of activities, especially professional, social and leisure activities. The situation experienced by individuals when economically active, with the demands of work, added to domestic activities and family obligations, encumbered their access to educational activities. As they liberated themselves totally or partially from such obligations, they sought UNATI as a way to fill the available time.

\section{One year after retirement I decided that I would like to continue studying. This is what pleases me and that is whyl sought the university experience [...] after 40 years leading a very active life, with a job, doing house chores, taking care of children and taking courses, and then suddenly staying home to dust the furniture, I realized I could go insane. (I-2 UNATI/UB)}

Retired and non-retired seniors who continued to exercise paid employment had positions with flexible schedules or lighter workloads than in previous phases of life. This allowed them to be able to reconcile other demands, so that UNATI was an option.

I have a job that does not require 15 hours a day, so I'm calmer, but I need to have a creative mind because I dedicate myself to communication and marketing. (I-10 UNATI/UB)

I go to UNATI to fill the time, to have something else to do and not to be stuck only to my work. (I-36 UNATI/UEM)

The interpretation that UNATI occupies free time with learning was linked to the improvement of health. This is because the elderly's perception of health included physical, mental and social aspects and converged with the proposed UNATI activities, seen as beneficial to shape behaviors with the purpose of maintaining and/or improving health.

I came to UNATI to occupy myself. I know the stuff that an old man has to keep himself busy, otherwise he goes insane. An old man has to deal with physical and mental health. By being active, by attending things, you feel useful in a lot of ways. (I-35 UNATI/UEM) 
It became clear that the understanding of available time is an individual construction, based on personal experiences and, consequently, on the symbolic construction developed through them. Such perception influences the attitudes of seniors of both nationalities, who act upon the perceived availability.

\section{The opportunity for access to learning in the university}

The desire to study and learn was inherent in life among the elderly of the two nationalities and did not arise only in old age, but that was the time of life in which they were able to fulfill it. In several situations, due to the family financial situation in which the need to work outweighed the yearning to study, and in the case of women, due to the cultural issues of the time, some seniors did not have the opportunity to go to college or even to complete formal education when they were young. In reflecting on the possible alternatives to compensate previous experiences, seniors pursued college studies, having their strategic access through UNATI.

I could not afford to study when I was young. I started working very early. Then the day university's doors were opened to me, I said 'now is my time.' (E-18 UNATI/UB)

I did not study in my time. My father thought a woman had to get married and go another way. I always liked to study, I always wanted to study and this opportunity came in handy. I say I was privileged. (E-23 UNATI/UEM)

For some interviewees, the difficulty in entering the university through selective processes required by higher education courses and relinquishing undergraduate or postgraduate courses due to the established requirements and criteria brought reflections about the obligations involved in formal education. Recognizing these difficulties, the action chosen was through UNATI.

Weakened by a previous heart attack, I was taking a course [in Law] that required a lot of reading and work. I would go to bed late because I had to do homework. UNATI leads you to do the readings on the subjects of your choice, without the obligation of taking a test and worry about failing it. That was my problem in law school, me, a 77-year-old getting bad grades. The day I scored less than 60 I went nuts, I was ashamed. Here at UNATI it is different, I am not that pressed. (E-29 UNATI/UEM)

In this sense, the reason that led to pursue UNATI was the opportunity to study without the criteria of formal education, since in UNATI there are no selective processes based on tests, no formal evaluations, and the criteria to be met for passing the disciplines are flexible. Such arrangements reassured the students and were seen as pleasurable ways of learning.

I cherished the idea of going back to school, because as a young man I had to quit school. And since at this point in life a degree is unnecessary, not having to take tests and study just for pleasure is very good. (I-20 UNATI/UB)

The opportunity to access UNATI attenuated the desire to take a regular undergraduate course, since it offers a variety of disciplines, which also deal with subjects related to areas that the elderly, in earlier stages of life, wanted to deepen in a formal college program.

I always wanted to study medicine, but I could not do it, and so I joined this course [health and well-being]. It was a pending subject in my life. I do not have to live from the past, I live from the present. (I-6 UNATI/UB)

The fact that UNATI allows the opportunity to choose the subjects they intend to attend was a strong influencer for joining this type of program. In this modality, students can direct their efforts to the topics of their interest and to advance in the sense of having more autonomy on the subject in question. This is illustrated by seniors who have an employment relationship and enrolled in disciplines to learn content that would be useful and facilitate the handling of work issues.

\section{The search for expansion and/or improvement of social relations}

The expansion of social relations was an exclusive motivation manifested by the Brazilian elderly. Retirement had broken the social relations maintained in the work environment, which in some cases was compounded by the loss of friends and spouses and culminated in restriction of bonds.

I came to UNATI in order to ward off my depression, which worsened after my wife's death [...] here we keep in touch with classmates outside class, even on weekends. (I-28 UNATI/UEM)

From the above and the emphatic perception that social relations impact positively on mental health, the need to develop new links arose and UNATI was an alternative. The motivation centered on the desire to know people's different ways of life and their experiences, to exchange experiences and knowledge and, above all, the desire to expand social networks.

What brought me to UNATI is being able to be more acquainted with the current world and to get along with young people [...] I was afraid I might get depressed at home, because that's what I was often told when I was about to retire. (I-41UNAT/UEM)

Restricted training and knowledge were considered a limitation for social interaction with peers, friends and family members. UNATI was sought in order to exchange knowledge and experiences with other seniors, teachers and younger generations, whose purpose was to broaden views on the most varied subjects and, consequently, to improve the dialogue and to have satisfactory connections with the people around.

I came because with UNATII'Il be able to discuss more with people about particular issues. My children have a college degree and my son-in-law too. Here I can learn and talk better with them. We get more up to date and manage to get a better dialogue with people. (I-36 UNATI/UEM)

Faced with difficulties in maintaining or expanding social relations, some older people sought UNATI as a way to expand their circle of friendships. They were also motivated to keep up with 
the constant changes in society and to improve existing social relations and those coming from UNATI attendance.

\section{DISCUSSION}

From the interaction with the situation lived - excess of free time with fear of having impaired health due to lack of activities; having had no access to university learning in the past; struggling to enter or continue formal undergraduate courses; and lack of social connections - seniors have built meanings and undertook the action of joining UNATI in order to modify behaviors and envisage a new reality that serves their interests.

The results reported here are similar to those of other studies, in which the influencers of the search for UNATI relate to the improvement of knowledge, expansion of social ties, occupation of free time ${ }^{(1,7-9)}$, investment in personal development, the need to have knowledge that can help people ${ }^{(1,9)}$, achievement of the dream of studying ${ }^{(8)}$ and improvement of the quality of life, health ${ }^{(7-8)}$ and family relationships ${ }^{(7)}$.

Certainly Brazilian and Spanish seniors experience different opportunities, mainly due to the difference between the processes of population aging across these countries. Spain is a nation that has undergone a demographic transition, with an increase in the number of aged people for some decades and thus a better policy consolidation for the elderly ${ }^{(14)}$. Brazil, on the other hand, began the process of population aging recently, experiencing it in an accelerated manner ${ }^{(13)}$, and has not had the time to implement solutions capable of dealing with the situation and meeting the needs of the elderly population ${ }^{(14)}$.

With the above-mentioned differences between the countries, added to cultural ones, we expected to find different reasons for seeking UNATI and be able to make a comparison with these results. However, the motivations of the elderly of these two scenarios were similar, except for the yearning for expansion of social coexistence, expressed only by Brazilians. In this regard, we reckon that the profile of older UNATI students does not reflect the reality of the older Spanish or Brazilian population. UNATI participants represent a group of individuals who have similar socioeconomic and health characteristics ${ }^{(1,15)}$ but who differ from those who do not attend educational programs.

Many elderly people consider retirement as a time to rest or develop leisure activities. The reflection of this is that they spend their free time engaged in few tasks ${ }^{(15)}$ and do not seek educational activities.

A Spanish study shows that the elderly population includes subgroups that are more interested in taking part in activities within the framework of UNATI. Younger olds (65-75 years of age) with a higher educational level, living in urban contexts, who engage in leisure and sports activities, attend recreational centers for the elderly and develop productive activities (such as caring for grandchildren or participating in voluntary activities) are more likely to pursue educational activities in old age. On the contrary, income and health perception were not factors associated with participation ${ }^{(15)}$.

A Brazilian study indicates that there is a correlation between certain sociodemographic characteristics and the reasons for seeking UNATI. Age (60-64 years) combined with high school were strong predictors for the search of new knowledge; being single and not retired was a predictor of investment in personal development; having only elementary school and being married was correlated with the desire to increase social interaction; being single or widowed and with a family income of three to four minimum wages was a predictor of free time occupation ${ }^{(1)}$.

It should be emphasized here that the motivation to occupy the free time may be due to the lack of a public policy that provides the elderly with access to different segments of society, which includes the provision of educational activities ${ }^{(15)}$. In the UNATI discussed in this study, for example, enrollment vacancies are distributed by lot because the demand outnumbers the supply. This poses a great challenge, since older people have several reasons to join UNATI but are faced with limited vacancies, which prevents their participation in such activities.

As for the difficulty of going to college as a young person, this was due both to financial factors and to the cultural patterns of the time. Men were the providers of family needs and women were responsible for taking care of the house and children ${ }^{(16)}$, and this arrangement made it difficult to reconcile learning at the university level. Only with the advent of retirement and changing cultural patterns could they have access to college through UNATI.

It is important to note that the aspirations of older people attending UNATI and formal university programs are slightly different. For the latter, motivations comprise the updating of knowledge and skills, the need to adjust to the competitiveness of the labor market, to keep abreast of social changes, and to have a first degree ${ }^{(4)}$. Although UNATI has been an alternative to undergraduate and graduate school because of the difficulty to enter and keep on such education level, age, to the eighth decade of life, is not associated with difficulty in academic performance ${ }^{(17)}$. We reiterate that the option for UNATI was given by the possibility of choosing disciplines and the flexibility of evaluations.

Even though it was not a motivation emphasized by the Spaniards, perhaps due to sociocultural issues, the expansion of social relations occurs when the elderly engage in university activities ${ }^{(18-19)}$, both at the generational and intergenerational levels. This brings satisfaction with the opportunity to exchange knowledge and discuss ideas with peers, undergraduates and teachers, as well as deepening understanding of the various subjects ${ }^{(19)}$.

Finally, the university, in offering educational programs such as UNATI, fulfills its social function. This is because learning is an inherent yearning in the human being, a continuous and endless process and, most of all, a necessity that guarantees personal fulfillment, enables intellectual exercise and improves health and well-being ${ }^{(3)}$. For the World Health Organization (WHO), the opportunities for learning in old age are determinants of active aging, since they optimize the opportunities for health, participation, safety and better quality of life $\mathrm{e}^{(17-18)}$. Such statements reinforce that policy makers and authorities need to be more attentive to the need for expanded access to such programs, and that they address the needs of older people ${ }^{(18)}$.

\section{Limitations of the study}

A limitation of the study is the fact that seniors from only two UNATIs participated, which, despite being located in distinct 
countries and social cultural contexts, have senior citizens with similar socioeconomic and health characteristics.

\section{Contributions to the area of nursing, health or public policy}

The understanding of the reasons that lead Brazilian and Spanish elderly people to enroll in UNATI contributes to the theoretical advance of the subject. This study provides support and intervention opportunities for UNATI managers to organize programs that effectively meet their students' expectations.

For nursing, the study suggests a relevant contribution, especially for its appreciable proximity to the elderly public in the various points of health care. Although nursing care practice is not directly linked to UNATI, nurses may use the reflections on the reasons for seeking such programs and encourage, where appropriate, the participation of seniors in these, as care alternatives.

\section{FINAL CONSIDERATIONS}

The motivations that led seniors to enroll in UNATI were related to the need of occupying the free time, including improvement of health; the opportunity of access to continuous learning for life in the university; and the expansion of social relations, the latter motivation being expressed only by the Brazilian participants. In view of the differences in the socioeconomic and cultural context between Brazil and Spain, we expected to find different reasons for seeking UNATI, but considering that the profile of the elderly enrolled in both countries is similar, the motivations turned out to be similar.

In considering the progress of research related to learning in old age, it is essential to implement evidence-based policies that incorporate adequate learning opportunities for these citizens, since it is about a clear path to achieve many benefits to the health, and in social and economic aspects. To this end, further studies are still needed to determine if the motivations and yearnings of the elderly when joining the UNATI are effectively met, as well as to capture the satisfaction of seniors who participated in such programs.

\section{FUNDING}

Conselho Nacional de Desenvolvimento Científico e Tecnológico (CNPq).

\section{REFERENCES}

1. Cachioni M, Ordonez TN, Silva TBL, Batistoni SST, Yassuda MS, Melo RC, et al. Motivational factors and predictors for attending a continuing education program for older adults. Educ Gerontol. 2014;40(8):584-96. doi: 10.1080/03601277.2013.802188

2. Formosa M. Four decades of Universities of the Third Age: past, present, future. Ageing Soc. 2014;34(1):42-66. doi: 10.1017/ S0144686X12000797

3. Aparicio JEV. Educación permanente: los programas universitarios para mayores en España como respuesta a una nueva realidad social. Rev Educ Sup [Internet]. 2014 [cited 2017 Nov 24];43(171):117-38. Available from: http://www.scielo.org.mx/pdf/resu/v43n171/v43n171a6.pdf

4. Chen L-K, Wang ST. Seniors' demographic correlates for motivations to enroll in degree-conferring programs in universities. Educ Gerontol. 2016;40(6):431-42. doi: 10.1080/03601277.2016.1139968

5. Gunder ES. Third age perspectives on lifelong learning: third age university. Procedia Soc Behav Sci. 2014;116:1165-9. doi: https://doi. org/10.1016/j.sbspro.2014.01.363

6. Adamo CE, Esper MT, Bastos GCFC, Sousa IF, Almeida RJ. University of the Third Age: the impact of continuing education on the quality of life of the elderly. Rev Bras Geriatr Gerontol. 2017;20(4):550-60. doi: 10.1590/1981-22562017020.160192

7. González SS, Prados ABN, Rodriguez JMM. Perfil, motivaciones e intereses de los aprendices mayores hacia los programas universitarios. Rev Educac Desarrollo Soc [Internet]. 2017 [cited 2017 Nov 26];11(1):156-71. Available from: https://revistas.unimilitar.edu.co/index.php/reds/ article/view/1863/2538

8. Pereira AAS, Couto VVD, Scorsolini-Comin F. Motivações de idosos para participação no programa Universidade Aberta à Terceira Idade. Rev Bras Orientac Prof [Internet]. 2015 [cited 2017 Nov 28];16(2):207-17. Available from: http://pepsic.bvsalud.org/pdf/rbop/v16n2/11.pdf

9. Zhao X, Fu Y, Chui EW. Motivations of older Chinese adult learners in Hong Kong. Curr Aging Sci. 2016;9(3):178-87. doi: 10.2174/187460980 9666160506122024

10. Charon JM. Symbolic Interacionism: an Introduction, an Interpretation, an Integration. $10^{\text {th }}$ ed. London: Pearson; 2009.

11. Strauss A, Corbin J. Pesquisa qualitativa: técnicas e procedimentos para o desenvolvimento de teoria fundamentada. $2^{\mathrm{a}}$ ed. Porto Alegre: Artmed; 2008.

12. Tong A, Sainsbury P, Craig J. Consolidated criteria for reporting qualitative research (COREQ): a 32-item checklist for interviews and focus groups. Int J Qual Health Care. 2007;19(6):349-57. doi: 10.1093/intqhc/mzm042

13. United Nations, Department of Economic and Social Affairs. World Population Prospects: The 2015 Revision, Key Findings and Advanced Tables. [Internet]. New York; 2015 [cited 2017 Dec 12]. Available from: https://esa.un.org/unpd/wpp/publications/files/key_findings_ wpp_2015.pdf

14. Beard JR, Bloom DE. Towards a comprehensive public health response to population ageing. Lancet. 2015;385(9968);658-61. doi: 10.1016/ S0140-6736(14)61461-6. 
15. Villar F, Serrat R, Celdrán M. Participation of Spanish older people in educational courses: the role of sociodemographic and active ageing factors. J Eur Soc Policy. 2016;26(5):417-27. doi: 10.1177/0958928716664295

16. Fischer SH, David D, Crotty BH, Dierks M, Safran C. Acceptance and use of health information technology by community-dwelling elders. Int J Med Inform. 2014;83(9):624-35. doi: 10.1016/j.ijmedinf.2014.06.005

17. Imlach A-R, Ward DD, Stuart KE, Summers MJ, Valenzuela MJ, King AE, et al. Age is no barrier: predictors of academic success in older learners. NPJ Sci Learn. 2017;2(13):1-7. doi: 10.1038/s41539-017-0014-5

18. Boulton-Lewis G, Aird R, Buys L. Older Australians: structural barriers to learning in later life. Curr Aging Sci. 2016;9(3):188-95. doi: 10.2174/18 74609809666160506122131

19. Brownie S. Older Australian's motivation for university enrollment and their perception of the role of tertiary education in promoting healthy aging: a national cross-sectional study. Educ Gerontol. 2014;40(10):723-36. doi: 10.1080/03601277.2014.886860 